\title{
THE VITALITY AND VIABILITY OF HEMOLYTIC STREPTOCOCCI IN WATER.
}

BY GEORGE S. LIVINGSTON, M.S.

(Received for publication Oetober 19, 1920.)

\section{INTRODUCTION.}

The subject of the viability and vitality of bacteria in water has been thoroughly investigated, mainly with reference to the bacterial content of natural waters to determine their potability. More especially has attention been centered upon Bacillus coli and its more dangerous relatives in the field of hygiene and public health, to the end of preventing and controlling the endemic and epidemic waterborne diseases. The scope of this work was extended to the streptococci, and the investigations here reported were conducted to ascertain their behavior and significance in water.

The early workers in this field reported on the mere presence of streptococci, with little attempt at classification. More recently the literature contains references to specific types which appear always to be of intestinal origin, and are usnally non-hemolytie.

The object of the present work was to obtain data on the vitality and viability of hemolytie streptococei in water, and to discuss the possible rôle which various waters containing these organisms might play in the spread of disease.

The earliest reference to streptococei in water is that of Roseoe and Lunt (1) in 1891, who found them in sewage. Laws and Andrews (2), in 1894, found them in sewage from St. Bartholomew's Hospital. Houston (3) in 1898 reported the first of an extensive series of studies on streptococei in water. Classification on the basis of hemolysis was not used at that time, but it may be judged from the source and nature of the organisms, that they were of non-hemolytic varieties. In the United States the first reference to streptococei in water was made in 1902, by Winslow and Hunnewell (4) who found them in sewage, in septic tanks, and in river water polluted by sewage.

It appears, then, that streptococei have been found in water con-

"From the Department of Bacteriology and Pathology, University of Illinois, College of Medicine, Chicago. 
taminated by excretions, and that where there is human fecal contamination the organism most commonly found is Streptococcus fecalis, a non-hemolytic variety. No reference can be found to hemolytic streptocoeci in water, but their occasional presence in feces suggests the possibility of finding them in water polluted by sewage. Holman (5) states that of fifty-three strains of streptococei from feces, thirteen were hemolytic, and that of thirty-eight strains from urine and the urethra, eleven were hemolytic. Oppenheim (5) found five hemolytic strains out of fifteen isolated from feces, and Broadhurst (7) reports that nine out of thirty-one fecal strains were hemolytic. Davis (8), however, found no hemolytic streptococei in the stools in fifty-three cases, many of whom harbored these organisms in their throats; he also found them absent from the stools of four scarlet fever patients. Moody and Irons (9) found them in the stools in thirty per cent. of cases of searlet fever. It appears, therefore, that hemolytic streptococei are rare and inconstant inhabitants of the excretions, and that the probability of their reaching water by this route is slight. That disease may be spread by water containing streptococci is suggested, however, by Wilson (10), who reports an epidemic of streptococcus pneumonia with intestinal complications, in a war camp. All of the patients gave a history of having drunk shell-hole water, the diarrheal symptoms ensuing from one to five hours after. Bacteriologieal examination of the water showed that twenty-eight out of forty-two samples contained streptococei in large numbers. Hemolytic activity was variable, but it appears that some of the strains isolated were hemolytic.

Hemolytic streptococei appear not to have a natural habitat outside the animal body. Broadhurst ( 7) examined eighteen samples of soil and water from wood edges, moist road-banks, and brooks, of which one sample of water, from a country roadside overfiow, showed short-chained micrococei ; these, however, were not hemolytic.

\section{EXPFRIMENTAL WORK.}

The experimental work of the problem comprised a series of tests to determine the vitality and viability of hemolytic streptococei in water, under various conditions. In these tests the general method employed was to place the water in a suitable vessel in measured amount, and seed it with a suspension of hemolytic streptococei. These were grown in pure culture on slants of blood-agar for forty-eight hours, at $37.5^{\circ} \mathrm{C}$. The growths were then removed by scraping the 
surfaces of the slants with a wire loop, and transferred to a tube of sterile distilled water. This gave a concentrated suspension of the bacteria in water, without admixture of any nutrient material from the culture medium. The suspension was shaken until it was of uniform opacity, and contained no large particles, and was then added to the water in Erlenmeyer flasks of Pyrex glass, to give the desired concentration. In those tests in which enumeration of the bacteria was not necessary, a qualitative examination was made at the time of seeding, and periodically thereafter, once a day, once in two days, or twice a week, as the conditions of the experiment required. For this purpose plates of blood-agar were used, inoculated with the water, and ineubated at $37.5^{\circ}$ for twenty-four hours. The plates were examined for the presence of hemolytic streptococeus colonies, and if found, the water was recorded as containing living hemolytic streptococci on the day on which the sample was taken. Negative plates were incubated for twenty-four hours longer, before recording them as such.

In certain experiments it was necessary to keep a daily record of the quantitative streptococcal content of the water. This was done by pouring blood-agar plates inoculated with accurately measured amounts of the water by the method of decimal dilutions. After the usual incubation, colonies were counted in the most suitable plate, and the number of hemolytie streptococei per cubic centimeter of water was calculated.

I. Longevity of various strains of hemolytic streptococci in sterile distilled water.

Eleven strains of hemolytic streptococei and one of Streptococcus viridans were selected for comparative study. All the strains were of human origin, and all were virulent at the time of isolation. All but. two of the strains had caused the death of the individual from whom they had been isolated, and these two were associated with acute infectious processes. The strains varied in age from one month to ten years. They were obtained from the following sources:

1. Abscess (autopsy).

8. Acute ulcerated appendix.

12. Lung; influenzal pneumonia (antopsy).

39. Lung; pneumonia (autopsy).

40. Tonsils; aeute tonsillitis.

84. Trachea; pneumonia (autopsy).

90. Heart blood; septicemia (autopsy). 
104. Pleura; pneumonia (autopsy).

113. Lungs; pneumonia (autopsy).

208. Cerebrospinal fluid; streptocoecus meningitis.

211. Fatal septic sore throat; during milk epidemic.

49. Streptococcus viridans; endocarditis (antopsy).

All the strains grew in chains of varying length, in liquid media; all were Gram positive; all grew in characteristic colonies on bloodagar plates, with a clear wide zone of hemolysis around the colony (except 49); none of them liquefied gelatin, and none fermented inulin. Each strain was added to 100 c.c. of sterile distilled water, in a cotton-plugged flask, by the method previously outlined, and the flasks were kept in the laboratory, at room temperature, in subdued light. The presence of hemolytic streptococei was determined qualitatively only, by plating on blood-agar. Plates were poured at the time the experiment was began, and twice a week thereafter, until negative plates appeared. Negative plates on three consecutive days, using one cubic centimeter of water, were taken as evidence that all streptocoeci in a given flask of water were dead.

TABLE I.

Longevity of various strains of hemolytic streptococci, in sterile distilled water.

\begin{tabular}{|c|c|c|c|c|c|c|c|c|c|c|c|c|}
\hline Days. & 104 & 12 & 113 & 49 & 40 & 39 & 90 & 84 & 211 & 8 & 208 & 1 \\
\hline 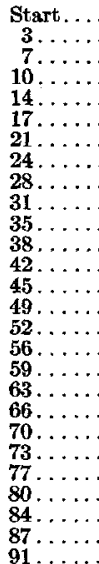 & $\begin{array}{l}+ \\
+ \\
+ \\
+ \\
+ \\
+ \\
+ \\
+ \\
+ \\
+ \\
+ \\
+ \\
+ \\
+ \\
+ \\
+ \\
+ \\
+ \\
+ \\
+ \\
+ \\
+ \\
+ \\
+\end{array}$ & $\begin{array}{l}+ \\
+ \\
+ \\
+ \\
+ \\
+ \\
+ \\
+ \\
+ \\
+ \\
+ \\
+ \\
+ \\
+ \\
+ \\
+ \\
+ \\
+ \\
+\end{array}$ & $\begin{array}{l}+ \\
+ \\
+ \\
+ \\
+ \\
+ \\
+ \\
+ \\
+ \\
+ \\
+ \\
+ \\
+ \\
+ \\
+ \\
+\end{array}$ & $\begin{array}{l}+ \\
\pm \\
\pm \\
+ \\
+ \\
\pm \\
+ \\
\pm \\
\pm \\
\pm \\
\pm \\
\pm \\
\pm \\
\pm\end{array}$ & $\begin{array}{l}+ \\
+ \\
+ \\
+ \\
+ \\
+ \\
+ \\
+ \\
+ \\
+ \\
+ \\
+ \\
+ \\
+\end{array}$ & $\begin{array}{l}+ \\
+ \\
+ \\
+ \\
+ \\
+ \\
+ \\
+ \\
+ \\
+ \\
+ \\
+\end{array}$ & $\begin{array}{l}+ \\
+ \\
+ \\
+ \\
+ \\
+ \\
+ \\
+ \\
+ \\
+ \\
+ \\
+\end{array}$ & $\begin{array}{l}+ \\
+ \\
+ \\
+ \\
+ \\
+ \\
+ \\
+ \\
+ \\
+\end{array}$ & $\begin{array}{l}+ \\
+ \\
+ \\
+ \\
+ \\
+ \\
+ \\
+ \\
+\end{array}$ & $\begin{array}{l}+ \\
+ \\
+ \\
+ \\
+ \\
+ \\
+\end{array}$ & $\begin{array}{l} \pm \\
\pm \\
\pm \\
\pm \\
\pm \\
\pm \\
\pm\end{array}$ & \pm \\
\hline
\end{tabular}


The results of this experiment show that the length of life of these organisms in water, under these conditions varies within wide limits. It is, in effect, a test of the resistance of each strain to starvation, since no nutrient material was present in the water. Strain J. was the first to succumb, no colonies appearing in plates after the third day. Strain 104 survived the longest, viz., eighty-seven days. The average length of life of all the hemolytic strains was thirty-eight days. The green-producing streptococeus, 49 , lived for fifty days. The average for all strains was thirty-nine days. In Table $I$ the strains are arranged in the order of their longevity.

II. Variation of longevity of a single strain of hemolytic streplococci, in different concentrations, in sterile distilled water.

A heavy suspension was made of strain 104, from a number of blood-agar slants. This was adjusted to contain approximately one billion streptococei per cubic centimeter. The suspension was added to flasks of sterile distilled water, in quantities to give a final content of 100 c. c. of water for each flask, the bacterial content varying as follows :

$$
\begin{aligned}
& \text { 1. } 100,000,000 \text { per c.c. } \\
& 2.10,000,000 \text { per c.c. } \\
& \text { 3. } 1,000,000 \text { per c.c. } \\
& \text { 4. } 100,000 \text { per c.e. } \\
& \text { 5. } 10,000 \text { per c.c. } \\
& \text { 6. } \quad 1,000 \text { per c.c. }
\end{aligned}
$$

These flasks were kept in the laboratory, at room temperature, in subdued light. Quantitative estimations of the bacterial content were made at the start of the experiment, and at two day intervals thereafter. Absence of colonies in plates, poured from 1 c.c. of water, on three successive days, was taken as evidence that all streptococi in a given flask were dead. Table II gives the detailed record of this experiment. The flasks are arranged in the order of their longevity. The bacteria in Flask I survived for fifty-two days, in Flask 2 for thirty days, in Flask 3 for twenty days, in Flask 4 for twelve days, in Flask 5 for six days; and in Flask 6 for four days. The results were quite uniform and significant. The greatest number of organisms died during the first week. After that the rate of decrease was less rapid. The greater the concentration of streptococei in a given flask of water, the longer they survived. The curve below 
shows the relation between the initial concentration of streptococei in water and their longevity.

\section{TABLE II.}

Variation in longevity of a single strain of hemolytic streptocscoi, in different concentrations, in sterile distilled water.

\begin{tabular}{|c|c|c|c|c|c|c|}
\hline \multirow{2}{*}{ Days. } & 1 & 2 & $\mathbf{3}$ & 4 & 5 & 6 \\
\hline & No. per c.c. & No. per c.c. & No. per e.c. & No. per c.c. & No. per c.e. & No. per c.c. \\
\hline 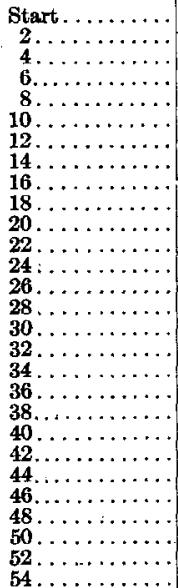 & $\begin{array}{r}100,000,000 \\
40,000,000 \\
9,000,000 \\
800,000 \\
300,000 \\
150,000 \\
90,000 \\
35,000 \\
22,000 \\
12,000 \\
4,500 \\
1,700 \\
1,100 \\
845 \\
670 \\
595 \\
230 \\
180 \\
195 \\
65 \\
23 \\
14 \\
3 \\
4 \\
5 \\
4 \\
\mathbf{2}\end{array}$ & $\begin{array}{r}10,000,000 \\
6,000,000 \\
1,500,000 \\
500,000 \\
95,000 \\
36,000 \\
8,500 \\
2,300 \\
650 \\
435 \\
210 \\
62 \\
18 \\
4 \\
7 \\
3 \\
0\end{array}$ & \begin{tabular}{|r}
$1,000,000$ \\
910,000 \\
250,000 \\
72,000 \\
13,700 \\
2,150 \\
890 \\
315 \\
84 \\
27 \\
6 \\
0
\end{tabular} & $\begin{array}{r}100,000 \\
6,300 \\
945 \\
124 \\
38 \\
14 \\
6 \\
0\end{array}$ & $\begin{array}{r}10,000 \\
451 \\
77 \\
8 \\
0\end{array}$ & $\begin{array}{r}1,000 \\
29 \\
3 \\
0\end{array}$ \\
\hline
\end{tabular}

III.' Longevity of a single strain of hemolytic streptococci in varions waters.

Samples of water were collected from various sources, and a suspension of strain 104 was added to each sample, in a flask. 100 c. c. of each kind of water were used, and the streptococcal content was adjusted to approximately 100,000 per c. c. The flasks were kept in the laboratory, at room temperature, in subdued light. The tests for viability were qualitative only. Blood-agar plates were poured daily. The routine technic was used. In addition, tubes of 1 per cent. dextrose bouillon were inoculated, and smears made after incubation for twenty-four hours. These were stained by Gram's method, and examined for streptococei. This was useful in those cases 
where the blood-agar plates were doubtful, owing to excessive contamination by other organisms. The sources of the various waters and the longevity of the streptococci, in each, are listed below.
1. Sterile distilled water
15 days
2. Sterile physiological salt solution $\ldots \ldots \ldots \ldots \ldots \ldots$ 12
3. Water from deep well $\ldots \ldots \ldots \ldots \ldots \ldots \ldots \ldots, 11$ "6
4. Water from surface well $\ldots, \ldots \ldots \ldots \ldots \ldots \ldots \ldots, 8$ "c
5. Water from Lake Michígan ............. 7 "6
6. Street water, sterilized in autoclave $\ldots \ldots \ldots \ldots \ldots, 6$
7. River water, Desplaines River ............ 6 \&
8. Water from country road-side diteh $\ldots \ldots \ldots \ldots \ldots$. 5 "
9. Street water, not sterile $\ldots \ldots \ldots \ldots \ldots \ldots \ldots \ldots$ 4 "6
10. Water from park lagoon $\ldots \ldots \ldots \ldots \ldots \ldots \ldots \ldots$ \&
11. Tap water $\ldots \ldots \ldots \ldots \ldots \ldots \ldots \ldots \ldots \ldots \ldots \ldots, 3 \ldots \ldots$
12. River water, Chieago River ............. 2

The average survival in all waters was seven days.

It is to be noted that these waters can be roughly divided into two groups, vị.:

$A$. The "clean" group, comprising those waters in which vitality was retained for the average length of time or longer, and

B. The "dirty" group, comprising those waters in which the streptococci died out in less than seven days. An exception is No. 11, tap water, in which all organisms were dead after three days. The experiment was later repeated, with sterile distilled water, as a control. The results were substantially the same, the streptococci dying sooner in tap water, in each case. This is attributed to the fact that the tap water used was quite heavily chlorinated. In all of the dirty waters other bacteria, the natural contaminators, were present in large numbers, after all streptococci were dead. It would seem that this was the main factor in determining the length of their vitality, they having been crowded out and overgrown by the saprophytes present. In Table III the water specimens are arranged in the order in which the streptocoeci survived.

IV. Effect of temperature on rate of decrease.

In this experiment three flasks, each containing 300 c.c. of sterile distilled water were seeded with a suspension of Streptococcus hemolyticus, strain 211, adjusted to approximately 100,000 per c.c. One flask was kept in the incubator at $37.5^{\circ} \mathrm{C}$, another at room temperature, in subdued light, the average being $27^{\circ} \mathrm{C}$., and the third 
GEORGE S. LIVINGSTON.

TABLE III.

Longevity of a single strain of hemolytice streptococoi in various waters.

\begin{tabular}{|c|c|c|c|c|c|c|c|c|c|c|c|c|}
\hline 网 Days. & 1 & 2 & 3 & 4 & 5 & 6 & 7 & 8 & 9 & 10 & 11 & 12 \\
\hline $\begin{array}{r}\text { Start } \ldots \\
1 \ldots \ldots \\
2 \ldots \ldots \\
3 \ldots \ldots \\
4 \ldots \\
5 \ldots \ldots \\
6 \ldots \\
7 \ldots \ldots \\
8 \ldots \\
9 \ldots \ldots \\
10 \ldots \\
11 \ldots \ldots \\
12 \ldots \\
13 \ldots \ldots \\
14 \ldots \ldots \\
15 \ldots \ldots \\
16 \ldots \ldots\end{array}$ & $\begin{array}{l}+ \\
+ \\
+ \\
+ \\
+ \\
+ \\
+ \\
+ \\
+ \\
+ \\
+ \\
+ \\
+ \\
+ \\
+ \\
+ \\
+\end{array}$ & $\begin{array}{l}+ \\
+ \\
+ \\
+ \\
+ \\
+ \\
+ \\
+ \\
+ \\
+ \\
+ \\
+ \\
+ \\
+\end{array}$ & $\begin{array}{l}+ \\
+ \\
+ \\
+ \\
+ \\
+ \\
+ \\
+ \\
+ \\
+ \\
+ \\
+\end{array}$ & $\begin{array}{l}+ \\
+ \\
+ \\
+ \\
+ \\
+ \\
+ \\
+ \\
+ \\
+\end{array}$ & $\begin{array}{l}+ \\
+ \\
+ \\
+ \\
+ \\
+ \\
+ \\
+ \\
+ \\
+\end{array}$ & $\begin{array}{l}+ \\
+ \\
+ \\
+ \\
+ \\
+ \\
+\end{array}$ & $\begin{array}{l}+ \\
+ \\
+ \\
+ \\
+ \\
+ \\
+\end{array}$ & $\begin{array}{l}+ \\
+ \\
+ \\
+ \\
+ \\
+ \\
+\end{array}$ & $\begin{array}{l}+ \\
+ \\
+ \\
+ \\
+\end{array}$ & $\begin{array}{l}+ \\
+ \\
+ \\
+ \\
+\end{array}$ & $\begin{array}{l}+ \\
+ \\
+ \\
+ \\
+\end{array}$ & $\begin{array}{l}+ \\
+ \\
+\end{array}$ \\
\hline
\end{tabular}

was kept in the refrigerator, at an average temperature of $1^{\circ} \mathrm{C}$. Quantitative plates were poured daily, and the number of surviving streptococei, per cubic centimeter, was caleulated. Strain 211 was one isolated during a milk epidemic from a fatal case of streptococeus sore throat. It was an old laboratory strain having been isolated ten years previously. In the incubator the streptocoeci re-

TABLE IV.

Effect of temperature on rate of decrease.

\begin{tabular}{|c|c|c|c|}
\hline \multirow{2}{*}{ Days. } & $37.5^{\circ} \mathrm{C}$. & $27^{\circ} \mathrm{C}$ & $1^{\circ} \mathrm{C}$ \\
\hline & No. per e.c. & No. per c.e. & No. per e.c. \\
\hline 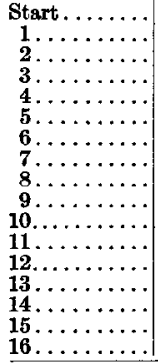 & $\begin{array}{r}100,000 \\
23,000 \\
3,400 \\
655 \\
48 \\
9 \\
2 \\
0\end{array}$ & $\begin{array}{r}100,000 \\
18,500 \\
7,200 \\
1,170 \\
415 \\
167 \\
38 \\
6 \\
15 \\
4 \\
0\end{array}$ & $\begin{array}{r}100,000 \\
37,000 \\
15,700 \\
4,200 \\
1,740 \\
885 \\
390 \\
187 \\
93 \\
43 \\
21 \\
27 \\
16 \\
4 \\
7 \\
3 \\
0 \\
\end{array}$ \\
\hline
\end{tabular}


tained their vitality, in water, for six days, at room temperature for nine days, and in the refrigerator for fifteen days. It appears, then, that survival is favored by low temperature, and is hindered by high temperatures. Too much importance, however, must not be attached to these figures, since they are not widely separated, and the differences are not sufficiently pronounced to be of much significance. Table IV gives the detailed record of these tests. It is to be noted that

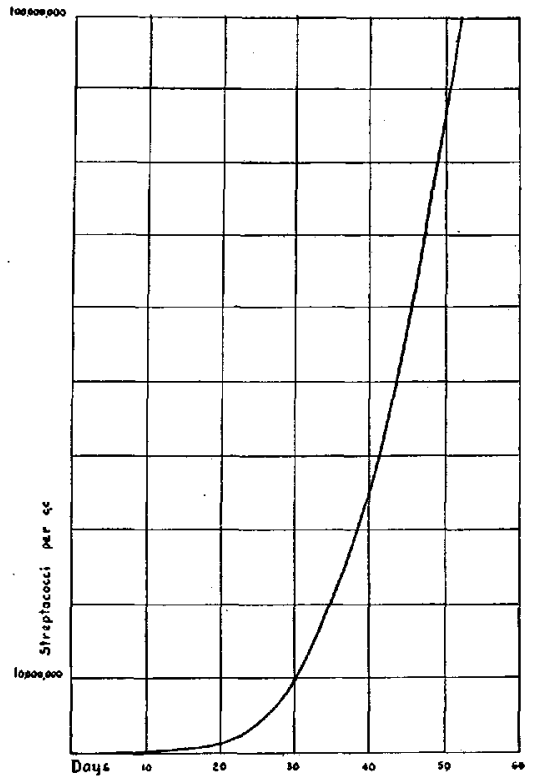

Curve showing relation of the concentration of streptococci to their longerity in water.

during the first week there was a rapid decrease in all three flasks. The rate of decrease is much less for subsequent days. The rapid decrease in the first week is quite constant, and appears to be characteristic. 
V. Comparison of longevity of virulent and avirulent strains of hemolytic streptococci, in sterile distilled water.

A number of strains of hemolytic streptococei was selected for this study, some from old laboratory cultures, others, recently isolated, from various human sources. Rabbits were inoculated with these strains to determine their virulence. 1000 gram rabbits were used., Each was given three cubic centimeters of a twenty-four hour broth culture of the strain used, injecting into the ear vein. Ten avirulent strains were chosen, viz., sueh as produced no change in the animals in two weeks; and ten virulent strains, each of which had produced arthritis and caused death in the rabbit inoeulated. Each strain was

TABLE $\mathrm{V}$.

Comparison of longevity of virulent and avirulent strains of hemolytic streptococci, in sterile distilled water.

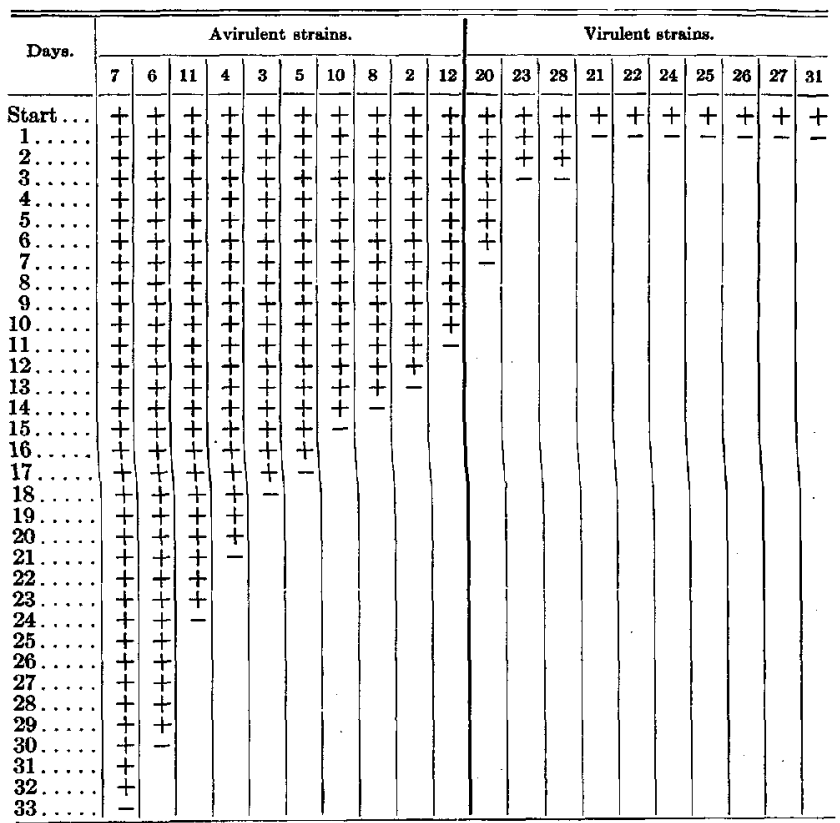


seeded in 100 c. c. of sterile distilled water, as in the previous tests, and kept at room temperature in the laboratory. Qualitative determinations were made daily. In Table $\mathrm{V}$ the varions strains are arranged, in the order of their longevity. The avirulent strains varied in their survival from ten to thirty-two days, averaging over eighteen days. Of the virulent strains one survived for six days, two for two days, and all the rest suceumbed within a day of the start.

\section{Discussion,}

In reviewing the results of the series of experiments set forth above, one is struck by the wide variations and the inconstancy in the behavior of hemolytic streptococci in water. Any conclusions which are drawn from this work must, therefore, be very general.

It is seen that hemolytic streptococei are capable of retaining their vitality when kept in water. In Experiment I the average period of survival was thirty-eight days, but one strain, 104, was able after being kept for eighty-seven days under these conditions, to multiply rapidly, when placed in a favorable environment. That the long period of survival was due in part to the enormous numbers originally placed in the water, is shown by the behavior of the same strain in various concentrations in Experiment II. Of a small number of streptococei in water, all will die out rapidly, but of a larger number a few individuals retain their vitality for a considerable length of time. Houston (3) tested a large number of streptococci in sterile tap water and sterile salt solution. Many died out in a few days, and those, that survived for forty or fifty days, showed a great decrease in their number.

Under more natural conditions the element of interferenee by other organisms becomes an important factor. Thus in waters of the "dirty" group, in Experiment III, hemolytic streptococci failed to survive for more than a week. Savage and Wood (11) found that streptococci of the intestinal variety die rapidly in sewage, and that most of them are dead at the end of two weeks.

In Experiment IV it was found that the rate of death, in water, is higher at body temperature than at room temperatures, and is lowest at $1^{\circ} \mathrm{C}$. The differences in the periods of survival at the various temperatures were not marked enough to be of great significance. Hinds (12), working with colon and typhoid bacilli, in natural and distilled water, found that the rate of death increased with the temperature. 
The greatest diminution in numbers was found in the first week. Those organisms which survived longer were eliminated more gradually. This agrees with the findings of Savage and Wood (11) with fecal streptococci. They conclude that the finding of streptococci in water is evidence of recent pollution.

Hemolytic streptococci, stored in water, always progressively decrease in their numbers, as shown by several of the quantitative tests. Savage and Wood found the same to be true of fecal streptococci, but noted that colon bacilli increased in number for a considerable length of time.

The effect of virulence is striking. In Experiment $V$ none of the virulent strains survived as long as the least viable of the avirulent strains. Most of them died ont over night. The evidence is quite definite that virulent hemolytic streptococei, recently isolated from lesions in the human body, are poorly adapted to storage in water, while old strains, long accustomed to artificial media, survive much longer.

\section{SuMMary,}

Hemolytic streptococei, when placed in water, remain alive for a variable length of time, depending upon their number, upon the temperature, upon the presence of other organisms, and upon virulence. They are capable under special conditions, of retaining their vitality for a long time, but under natural conditions, if placed in water, they will succumb quite rapidly, especially if recently isolated.

\section{LITERATURE,}

1. Quoted from Winslow and Hnnnewell (4).

2. Ibid.

3. Ibid.

4. WINSLOW, C.-E. A. AND HUNNEW ELI, M. P

1902. Streptococei characteristic of sewage and sewage-polluted waters apparently not hitherto reported in America. Seience, N. S.

5. HoLMAN, W. L. $\mathrm{XV}, 827$.

1916. The classification of streptococci. Journ. Med. Res., XXXIV, 377.

6. OPPENHEIM, C. J.

1920. The human fecal streptococei. Journ. Inf. Dis, XXVI, 117.

7. BRondHURST, JeAN.

1915. Environmental studies of streptococci. Journ. Inf. Dis., XVII, 277.

8. Davis, D. J.

1919. Hemolytio Streptocoeci with special reference to their rôle in acute respiratory infeetions. Journ. A. M. A., LXXII, 319. 
9. MOODY, W., AND IRONS, E. E.

1920. On the oceurrence of hemolytie streptococei in the stools of searlet 10. WiLson, J. A.

fever. Journ. Inf. Dis., XXVII, 363.

1918. Streptococcus infections of the respiratory tract. War Medicine, II, 556.

11. Sayage, W. G. AND WoOd, D. R.

1917. The vitality and viability of streptococei in water. Journ. Hyg., XVI, 227.

12. Hinds, M. F.

1917. University of Illinois Bull. 14, No. 5, and Water Strvey Series, 1917, No. 13, 225. 